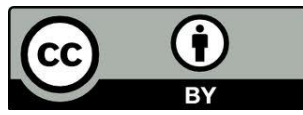

\title{
INTEGRISMO CATÓLICO E FUNDAMENTALISMO PROTESTANTE COMPARADOS: HISTORICIDADE, APROXIMAÇÕES E DISTANCIAMENTOS
}

\author{
Comparison of Catholic integrism and Protestant fundamentalism: historicity, \\ similarities and disparities
}

Marcos Gonçalves

Professor da Faculdade Estadual de Filosofia, Ciências e Letras de Paranaguá - FAFIPAR marcos.goncalves@ fafipar.br

Resumo: O artigo discute em perspectiva histórica e comparada, as manifestações produzidas pelo integrismo católico e o fundamentalismo protestante, procurando apontar para os paradoxos das atitudes desses movimentos em face aos fenômenos da modernidade. Indaga sobre as economias que impulsionam as interdependências, os conflitos e os afastamentos teóricos e doutrinários que se destacam na relação integrismo/fundamentalismo. Assim como, reconstitui os possíveis elementos históricos e políticos que, a partir do final do século XIX, contribuíram para a emergência de tais tendências no conjunto de práticas contemporâneas do cristianismo.

Palavras-chave: integrismo católico, fundamentalismo protestante, religião e política.

Abstract: The paper discusses the manifestations originated by catholic integrism and protestant fundamentalism in a historical and comparative perspective, trying to point out paradoxical attitudes of those movements in face of modernity's phenomena. It questions about economies that trigger interdependencies, conflicts and theoretical and doctrinarian separation highlighted in the integrism/fundamentalism relationship as well as reconstitutes historical and political elements that have possibly contributed to the appearance of those tendencies within the Christianity contemporary set of practices. Key words: Catholic integrism, protestant fundamentalism, religion and politics. 


\section{Introdução}

Em 1992, a renomada Concilium, revista teológica de amplitude internacional fundada na década de 1960 por eminentes teólogos - Metz, Boogaard, Brand, Congar, Kung, Rahner e Schillebeeckx - publicava o Dossiê Temático "Ecumenismo", dedicado especificamente aos estudos sobre os fundamentalismos contemporâneos. ${ }^{1}$ No mesmo ano, o não menos eminente sociólogo brasileiro Antonio Flávio Pierucci publicava na Revista USP o artigo Fundamentalismo e integrismo: os nomes e a coisa, ${ }^{2}$ no qual debatia as implicações políticas e religiosas contidas nos imaginários e ações produzidos por fundamentalistas e integristas, respectivamente, no islamismo e no cristianismo. Nele, Pierucci ainda destacava a relação desses grupos com os valores modernos, colocando ênfase na modulação radical e intransigente que tendia a malograr qualquer negociação quanto à convivência com o mundo da laicidade.

Seria o caso de, duas décadas depois desses estudos que se tornaram clássicos sobre a questão, revisitá-la na perspectiva de torná-la legível, sobretudo, apropriandonos das leituras que a camada de tempo histórico integrou aos saberes sobre os dois fenômenos? Ou, como estabelecer índices comparativos, distanciamentos e aproximações entre o integrismo e o fundamentalismo a partir do legado teórico e metodológico deixado por duas referências centrais na apreensão sobre o objeto? Embora sejam patentes as inevitáveis limitações (e incertezas) que um artigo sobre o tema comporta, o propósito é contribuir na compreensão sobre duas tendências próprias ao cristianismo: o integrismo católico e o fundamentalismo protestante, marcando alguma distinção com os textos que nos inspiram, sobretudo, pelo emprego de um regime de historicidade que acentue os "pontos de partida" de cada uma das manifestações. Sem atribuirmos relevância sobre o que comumente tem sido designado no ocidente por "fundamentalismo islâmico", o núcleo deste artigo estará, pois, na reflexão sobre a dialética de dois fenômenos germinados em solo cristão. Sua complexidade é majorada na medida em que a lógica determinada pelos padrões das democracias liberais contemporâneas - tomando como lembrança países como Estados Unidos e Brasil - coloca em jogo acirradas disputas que impõem aos “jogadores” uma

\footnotetext{
${ }^{1}$ Revista Concilium, Petrópolis, 241 - Dossiê Ecumenismo, 1992-3.

2 PIERUCCI, Antonio Flavio. Fundamentalismo e integrismo: os nomes e a coisa. Revista USP, São Paulo, n. 13, p. 144-156, mar/mai 1992.
} 
dependência que se desdobra: responder às exigências do mercado religioso que se deslocam invariavelmente para os resultados instrumentais auferidos - lucros e perdas no mercado político. O primeiro aspecto parece sinalizar para o colapso das identidades religiosas herdadas, como se referiu Hervieu-Léger (2008) sobre a crise de transmissão regular das instituições e dos valores de uma geração a outra, notadamente, a crise que atinge e absorve as significações das ditas grandes religiões históricas. ${ }^{3} \mathrm{Na}$ impossibilidade de lidarem com a "continuidade" sem descambarem para a "imutabilidade" católicos integristas e protestantes fundamentalistas não aceitam as rupturas culturais próprias de uma época de flutuações religiosas e desinstitucionalização eclesiástica, em contraste, sendo eles mesmo agentes promotores desses fenômenos.

No segundo aspecto, integristas e fundamentalistas motivam não apenas e obviamente, uma problemática religiosa segregada às igrejas, mas configuram e ampliam um conflito político e cultural pela gestão dos bens de salvação sob a forma de bens políticos e pela concorrência na tomada de espaços públicos. Mas não somente isto: como observou Schlegel (2009), tanto a mídia quanto a opinião pública não distinguem integristas e fundamentalistas. Ao nomeá-los genérica e simplificadamente de radicais ou fanáticos religiosos, esses meios deixam de prestar atenção ao tipo de relação que os movimentos assim caracterizados concretizam, por exemplo, com os fenômenos que marcaram o desencaixe moderno: crítica histórica, ciências, tecnologias, direitos humanos, política democrática, e claro, no limite, e como resultado a secularização. Se as duas terminologias no vocabulário dos especialistas designam "em bloco e no sentido amplo indivíduos e grupos, atividades e ideias, comportamentos e doutrinas que, em nome da religião, rejeitam, sem nuances e às vezes violentamente" ${ }^{4} \mathrm{a}$ dimensão axiológica do mundo moderno e as diferenciações decorrentes, trata-se de interrogar, sempre na perspectiva histórica, quais os paradoxos que interferem nessas atitudes que não são unívocas em face da modernidade e quais as imagens que integristas e fundamentalistas projetam ou projetaram de si mesmos e do outro.

3 HERVIEU-LÈGER, D. O peregrino e o convertido: a religião em movimento. Trad. João Batista Kreuch. Petrópolis: Vozes, 2008.

${ }^{4}$ SCHLEGEL, J. L. A lei de Deus contra a liberdade dos homens: integrismos e fundamentalismos. Trad. de Eduardo Brandão. São Paulo: Editora WMF Martins Fontes, 2009, p. 7-8. 


\section{Integrismo - pontos de partida}

$\mathrm{O}$ integrismo católico sintetizou na primeira década do século $\mathrm{XX}$, e sob o pontificado de Pio X (1903-1914), a árdua tarefa de manter intacto o espírito "íntegro" e a concepção jurídico-institucional-hierárquica da Igreja romana diante da teologia dos teólogos modernistas, assim acusados pelo Vaticano, e que propunham desde finais do século XIX, reformas na ortodoxia e nos métodos de exegese, avanços na crítica sobre os limites da filosofia tomista, conexão entre igreja, política e mundo moderno e o papel mais efetivo da democracia cristã.

Os textos fundadores do integrismo são três: a encíclica Pascendi Dominici gregis, o decreto Lamentabili sane exitu, ${ }^{5}$ ambos de 1907, e o juramento antimodernista Sacrorum antistitum, de 1910. Essa trilogia integrista marca para a Igreja da época o rol de condenações, prescrições, desconfiança e política de vigilância sem atenuantes produzidos para conter o "progressismo" contido na teologia de alguns recalcitrantes modernistas que teriam encabeçado a tentativa de reformas: mais notadamente Lucien Laberthonière e Alfred Loisy na França, George Tyrrell na Irlanda, Romolo Murri e Ernesto Buonaiuti na Itália. O emprego da categoria integrismo no interior da Igreja, serviu, pois, para afirmar a oposição dos representantes da ultra-ortodoxia baseada no "catolicismo oficial" e romano que reivindicava uma sociedade confessional, de fé católica integral, apoiada nos dogmas e no suposto de inerrância do texto papal frente aos postulados pelos setores modernistas internos.

O integrista francês Jean Madiran, no texto defesa ao integrismo publicado em 1964 afirmou: "Des catholiques de divers pays européens, dans les anées qui précédérent la guerre de 1914, se proclamaeint eux-mêmes 'catholiques intégraux'. Leurs adversaires les dirent donc intégristes avec une intention pejorative". 6

Em retrospectiva, a eleição de Pio X em 1903 não foi somente o recrudescimento e radicalização de um processo anterior já manifestado no final do pontificado de Leão XIII (1878-1903); foi mesmo a ruptura por esgotamento desse processo e uma reação conservadora em relação às tendências qualificadas como

\footnotetext{
5 Equivalente ao Sílabo de Pio IX no século XIX que condenava e recusava a transigir com o liberalismo, o decreto Lamentabili sumariava os sessenta erros mais graves dos modernistas católicos. A questão mais delicada, porém, é que as "heresias" modernistas estavam e foram produzidas dentro da Igreja.

${ }^{6}$ MADIRAN, J. L'intégrisme: histoire d'une histoire. Paris: Nouvelles Editions Latines, 1964, p. 8.
} 
modernizantes no interior da Igreja, e às ideologias políticas situadas à contra mão da doutrina que defendia a união entre Estado e Igreja. ${ }^{7}$ Desconfiado de qualquer empenho que visasse mais colegialidade na unidade estrutural da burocracia romana, Pio $\mathrm{X}$ pautou grande parte de suas ações guiado por uma mentalidade antimoderna. Posicionou-se francamente contra os partidos confessionais, contra o progressismo de setores católicos na França republicana e os sillonistas de Marc Sangnier. Segundo Mattei (2002), Pio X se destaca, através da Pascendi, por introduzir oficialmente o termo modernismo no vocabulário da Igreja romana ao defini-lo como um núcleo originário de erros em todos os campos da doutrina católica. ${ }^{8}$

Contudo, o modernismo religioso era uma presença molecular na Igreja pelo menos desde o último terço do século XIX, e, segundo Zagheni (1998) fermentou nessa cultura dual, atenta à modernidade e aos problemas sociais, mas também defensora intransigente das prerrogativas conservantistas da cúria romana. ${ }^{9}$ Os modernistas propunham uma abertura radical do cristianismo às exigências filosóficas do mundo moderno, e perseveravam, como Romolo Murri na Itália, na discussão sobre o conceito tradicional de Igreja no tocante à ordem política e social, e na intervenção dos católicos na competição partidária. Com o desenvolvimento das ciências e da correspondente especialização em todo o século XIX, verificou-se o emprego mais corrente dos métodos histórico-críticos na exegese bíblica, acirrando a atmosfera de perturbações pela qual iriam se defrontar duas propostas antagônicas de catolicismo nos primeiros anos do século passado: a integrista, que emerge mais enfaticamente da crise, de inspiração ortodoxa, absolutista, hierárquica e monopolista; e a modernista, de programa variado e movediço, indeterminado nas suas posições polarizadas entre a moderação e o extremismo. As bases metodológicas do modernismo e que atingiram o cerne do conflito com a hierarquia eclesiástica estão situadas em dois de seus princípios gerais: a imanência vital e a crítica histórica na exegese. O princípio da imanência, como método de apologética religiosa foi objeto da reflexão da filosofia de Maurice

\footnotetext{
7 Em 1906 Pio X condenou a separação entre Estado e Igreja na França, através da encíclica Vehementer Nos, elaborando uma doutrina excessivamente pessimista face à questão. Cf. PIO X, papa. Carta Encíclica Vehementer Nos - 11 de fevereiro de 1906: Sobre as Relações entre a Igreja e o Estado. Petrópolis: Vozes, 1952.

${ }^{8}$ MATTEI, R. de. Modernismo e antimodernismo nell'epoca di Pio X. In: BUSI, Michele, et al. Don Orione negli anni del modernismo. Milano: Editoriale Jaca Book Spa, 2002, p. 32.

9 ZAGHENI, G. A idade contemporânea. Curso de História da Igreja IV. Trad. José Maria de Almeida. São Paulo: Paulus, 1998, p. 254.
} 
Blondel em dois textos: Lettre sur les exigences de la pensée contemporaine en matière d'Apologétique de 1896, como processo que aprofunda sua tese sobre a filosofia da ação (L'Action: essai d'une critique de la vie et d'une Science de la pratique) de 1893. Esforçado em demonstrar que o sagrado é de alguma maneira, imanente ao homem, Blondel, mesmo sem ser um modernista, influenciou profundamente teólogos como Loisy que propôs o imanentismo, pelo menos, sob duas formas de interpretação: 1) Deus revela-se imediatamente (sem intermediários) à consciência do homem e é o princípio metafísico dessa consciência; 2) Deus é, sobretudo, um princípio de ação, e a experiência religiosa é uma experiência prática. ${ }^{10}$ De modo que a imanência implica no questionamento ao transcendental e aos critérios extrínsecos e formais para que o homem apreenda sua dimensão religiosa. Situando a origem das verdades religiosas nas necessidades vitais do homem, toma como parâmetro a valorização de uma experiência religiosa interior única e intransferível. A consciência, necessariamente, não exterioriza a sua busca pelo sagrado; a religião é um sentimento, e o encontro com Deus acontece no íntimo do ser humano. Nesse princípio tende a se afirmar uma descaracterização da objetividade da teologia da revelação, seja porque a luz da razão é insuficiente ou não é condição única para alcançar a Deus e nem o demonstra; seja porque o sagrado é capturado intuitiva e afetivamente no fundo da consciência pela construção de um sentimento. A necessidade do sagrado é gerada por tal sentimento, diga-se, autônomo, subjetivo, de modo que uma religião-Igreja específica é dispensável, bem como o logos da religião é destituído de centralidade em favor do phatos. Sendo a consciência o princípio que gera o sentimento da fé, todo homem "ascende" a Deus desobrigado de uma mediação externa.

Por contradição, a imanência é a revelação dentro do próprio homem. Uma vez que a última não pode tornar-se crível por manifestação externa, a resolução de uma realidade religiosa opera-se por disposição subjetiva no nível da consciência. Esse prescindir dos princípios racionais de demonstração infere que a revelação e a consciência, ambas intrínsecas ao homem, devem sujeitar a autoridade de qualquer

\footnotetext{
${ }^{10}$ ABBagnano, N. Dicionário de Filosofia. Trad. Alfredo Bosi. 2. ed. São Paulo: Martins Fontes, 1998 , p. 540.
} 
Igreja. Neste sentido, defendia, sobretudo, Alfred Loisy, nem mesmo a Igreja católica é excetuada, pois é ela também um processo de imanência na consciência de Cristo. ${ }^{11}$

Vital, da mesma forma para os modernistas, é a evolução que deve incidir sobre a crítica textual, por onde se configura a apropriação do método histórico-crítico na exegese bíblica. A crítica histórica estabelece a relação entre a asserção do narrador, operação subjetiva e imaginativa, e aquilo que se vê representado na realidade externa. O método histórico-crítico ou a crítica histórica na interpretação da escritura não era um fato novo para a Igreja de fins do século XIX e início do século XX. Muito menos era algo imune a condenações ou conflitos intelectuais. Hartlich (1980) lembrou das opiniões do teólogo Abraham Schultetus em 1618 reivindicando a utilização de disciplinas não teológicas e a leitura de autores profanos para uma compreensão maior das escrituras. Seis décadas mais tarde apareceram Richard Simon e o protestante Pierre Bayle questionando a atribuição de autoria mosaica ao Pentateuco, e a exigência de submissão dos textos à dúvida metódica. ${ }^{12}$

A indagação central, então, em algumas manifestações dos séculos XVII e XVIII, e revitalizadas pelos modernistas católicos em chave contemporânea era, em que medida, muitas narrações bíblicas podiam ser tomadas como verdades históricas, e até que ponto o método histórico-crítico contribuía para lançar luz sobre essa narrativa, surgindo assim como alternativa aos métodos empregados pela escolástica?

O modernismo foi condenado oficialmente pela encíclica Pascendi em $1907 .^{13}$ Esse documento da Igreja pode ser considerado o paradigma antimoderno do catolicismo no século XX e sua repercussão continuamente tem levantado questões nas consciências dos intelectuais católicos. Particularmente, tanto algumas organizações integristas no Brasil, como TFP e Hora Presente nas décadas de 1960 e 1970 aturdidas com o "progressismo" católico durante a ditadura, e, mais recentemente, a Montfort e a Lepanto, utilizando seus canais de divulgação na internet fazem menção honrosa das principais referências antimodernistas contidas na trilogia integrista de Pio X, como, de

11 Principalmente em: LOISY, A. L'Evangile et L'Eglise. Paris: Chez L'Ateur, 1908. Cf. também: LOISY, A. Prelude to the Modernist Crisis: The Firmin Articles of Alfred Loisy - American Academy of Religions in Translation. Oxford: Oxford University Press, 2010.

12 HARTLICH, C. Estará superado o método histórico-crítico? In: Concilium/158 - 1980/8. Ecumenismo, p. 6.

13 PIO X, papa. Carta Encíclica Pascendi Dominici Gregis - 08 de setembro de 1907. Petrópolis: Vozes, 1948. 
modo mais abrangente, após o Concílio Vaticano II, integristas como Marcel Lefebvre continuaram refutando as teses modernistas que persistiram ao tempo ou se amalgamaram a outras representações. Lefebvre, por exemplo, acusou abertamente o Vaticano II de transigir com o liberalismo moderno e com a apostasia. ${ }^{14}$ Ao condenar o modernismo, a Pascendi proscrevia os traços essenciais nas ideias modernistas, ou como ficou conhecido, o modernismo era o rendez-vous de todas as heresias. O agnosticismo, o naturalismo, o pragmatismo, o evolucionismo presentes no pensamento modernista representavam um salto para o ateísmo e para a desagregação do catolicismo. Na versão da Pascendi, os modernistas costumavam "apresentar suas doutrinas não coordenadas e juntas como um todo, mas dispersas e como que separadas umas das outras, a fim de serem lidos por duvidosos e incertos". ${ }^{15}$ Daí a necessidade de a própria encíclica organizar os nexos doutrinários entre os teóricos modernistas: o filósofo, o crente, o teólogo, o historiador, o crítico, o apologista e o reformador.

Embora reconhecesse que os fautores do erro não se achavam fora da Igreja, entre os "inimigos declarados", a encíclica alertava para a completa quebra de hierarquia na reivindicação modernista quanto às relações da Igreja com a sociedade. Ora, para uma reforma pleiteada no modelo modernista, cabia à Igreja a submissão ao espírito do tempo, que não somente a rebaixaria; sobretudo, a obrigaria a prestar honras às leis mundanas:

Acresce ainda que não é só dentro do seu recinto que a Igreja tem com quem entender-se amigavelmente; mas também fora. Não se acha ela só no mundo a ocupa-lo; ocupam-no também outras sociedades, com as quais não pode deixar de tratar ou de relacionar-se. (...) Deve, portanto, a Igreja separar-se do Estado, e assim também o católico do cidadão. E é por esse motivo que o católico, não se importando com a autoridade, com os desejos, com os conselhos e com as ordens da Igreja, e até mesmo desprezando as suas repreensões, tem direito e dever de fazer o que julgar mais oportuno ao bem da pátria. Querer, sob qualquer pretexto, impor ao cidadão uma norma de proceder, é por parte do poder eclesiástico verdadeiro abuso, que se deve repelir com toda a energia. ${ }^{16}$

Ponto bastante evocado pelos integristas está na possível influência da teologia protestante e do kantismo sobre o modernismo católico. Um texto de 1910 produzido no

14 LEFEBVRE, M. Do Liberalismo à Apostasia. A Tragédia Conciliar. Trad. Ildefonso Albano Filho. Rio de Janeiro: Permanência, 1991.

15 Cf. Pascendi, op. cit., Parágrafo 4, p. 5.

16 Idem, Parágrafo 24, p. 25-26. 
calor dos acontecimentos por Isidro Gomá, futuro primaz da Espanha e, durante a guerra civil (1936-1939) ardoroso franquista, auxilia-nos a esclarecer tais conexões. Seu Tradición y Crítica en exégesis: orientaciones de la apologética bíblica moderna deriva de uma comunicação apresentada ao Congresso Internacional de Apologética realizado em Vich, Espanha, em setembro daquele ano, e é uma obra claramente inspirada na ortodoxia integrista, afinada com as diretrizes da Pascendi. O fato primordial da exposição de Gomá é o estabelecimento das raízes do modernismo religioso. Elas estão sustentadas em dois pilares: a reforma protestante e o criticismo kantista: "La moderna concepción religiosa se basa en una doble autonomía; autonomía en orden á la fé; (...) autonomía en orden á la ley que regula en los espíritus la vida de fé”. Faltava a Lutero, porém, a base de uma sistematização filosófica para dar consistência à nova concepção religiosa. Esta é provida pelo subjetivismo e criticismo saídos do kantismo, os quais teriam produzido um duplo fenômeno:

De una parte, una religión híbrida que ha perdido su carácter sobrenatural y divino; de otra, una razón procaz que, desligada de toda autoridade divina y humana ha sabido hablar en los ressortes de su propia actividad el origen, el desarollo, las leyes y hasta el mismo objeto de su religión. ${ }^{17}$

Gomá apontava na teologia alemã uma crítica sagaz e tendenciosa, e na disposição tenaz para o trabalho de investigação empírica do "genio teutón", uma audácia sem limites de ordem especulativa, que foi causa desde o século XVIII de estragos nos dois livros testamentários.

Ao lado do empirismo e da investigação histórica, "el ingente esfuerzo realizado por la crítica alemana ha fascinado los espíritus y ha llevado la corriente de los estúdios bíblicos, hasta en el campo católico, fuero de su legítimo cauce”. ${ }^{18}$ Recentemente, a crítica textual efetuada por José Augusto Mourão parece ter endossado em parte as argumentações de Gomá. ${ }^{19}$ A luta dos modernistas para a contenção de um discurso hegemônico do magistério eclesiástico, além de configurar uma querela mutuamente excludente enunciada pelas dicotomias filosofia tradicional versus crítica filosófica/neotomismo versus escola kantiana, também era o reconhecimento da defasagem crítica da

17 GOMÁ, I. Tradición y Crítica en exégesis: orientaciones de la apologética bíblica moderna. Barcelona: Gustavo Gili Editor, 1910, p. 9-10.

18 Idem, p. 14.

19 MOURÃO, J. A. Crítica textual e modernismo - Em torno do decreto Lamentabili e da encíclica Pascendi. In: Revista de Recensões de Comunicação e Cultura. Lisboa, n. 6/7, p. 365-371, 1988. 
teologia católica no seu embate com a teologia "liberal e moderna" do protestantismo. Neste sentido, privada de inovações, movida em seus aspectos formais por um triunfalismo predominante, a exegese católica tradicional do século XIX, estava, segundo Mourão, estreitamente ligada à teologia dogmática da contra-reforma. No impacto político, cultural e teológico do movimento modernista encontra-se a gênese da Pascendi. Com ela, inaugurar-se-ia uma versão mais radical do dogmatismo para evitar que a Igreja mergulhasse, ou no subjetivismo dominado pelo imanentismo - e aí, o risco de reduzir o catolicismo a uma fé particular, sem publicidade - ou, tão importante, para obstruir a independência de uma crítica que aproximasse a Igreja da história; em outras palavras, para evitar que a Igreja fosse alvo de um processo de humanização.

\section{Fundamentalismo - pontos de partida}

O texto fundador do fundamentalismo protestante está reunido no conjunto de doze volumes que somam noventa artigos, publicados entre os anos de 1910 a 1915 sob o título The Fundamentals, com uma versão recente em português publicada em 2005 . ${ }^{20}$ Ele foi uma resposta ao modernismo teológico (ou teologia liberal) desencadeado desde meados do século XIX nos Estados Unidos por uma espécie de reação racionalista diante da mentalidade evangélica de natureza revivalista. Um dos aspectos cruciais dessa reação é que movimentos de reformas teológicas, modernistas, de fins do século XIX propuseram uma nova abordagem sobre os regramentos da fé, calcados, sobretudo, em uma profunda reinterpretação escriturística, e na apropriação das ciências evolucionistas. A industrialização acelerada, o liberalismo na política, a intensa imigração, o impacto do darwinismo nos sistemas educacionais, a crítica radical semeada pela exigência de um evangelho social e separado de uma ética essencialmente ascética desestabilizaram as bases teológicas de um protestantismo conservador, intransigente à mudanças. Velasques Filho resumiu em sete pontos o principal do programa do modernismo teológico protestante: 1) evolucionismo; 2) teoria das fontes na rejeição à autoria mosaica do Pentateuco; 3) influência e historicidade na troca de experiências culturais das religiões dos povos vizinhos de Israel na formação do

\footnotetext{
20 TORREY, R. A. Os Fundamentos: a famosa coletânea de textos das verdades bíblicas fundamentais. Editado por R. A. Torrey; atualizado por Charles L. Feinberg e outros; introduções biográficas de Warren W. Wiersbe. Trad. Cláudio J. A. Rodrigues. São Paulo: Hagnos, 2005. [Originais de 1910 a 1915]. Daqui a diante será referenciado neste artigo como Os Fundamentos.
} 
judaísmo primitivo; 4) revelação progressiva ou evolução gradual na formulação de crenças e costumes dos povos determinada por fatores naturais, econômicos, políticos e religiosos; 5) naturalismo filosófico; 6) crítica à deturpação paulina do cristianismo primitivo; 7) aceitação do emprego de métodos e técnicas originários das ciências históricas, sociais e naturais no estudo da bíblia e de seus manuscritos. ${ }^{21}$ Diante do que foi julgado pelos grupos conservadores como apostasia moderna, o fundamentalismo se realiza, em paráfrase ao texto de Pierucci, como fenômeno histórico ocidental, cristão, protestante e norte-americano. Há, no entanto, propensão razoável da parte de os estudiosos vincularem sem mediações o fundamentalismo ao integrismo católico, ou considerarem o último como uma "variante católica do fundamentalismo", ${ }^{22}$ sobretudo, após as inquietações despertadas pelo Concílio Vaticano II.

Embora possamos reconhecer parentescos em ambas as manifestações, a associação direta entre fundamentalismo e integrismo parece estar validada somente quando os argumentos centrais convergem em quatro aspectos inequívocos: 1) a contemporaneidade das duas modalidades; 2) a ameaça percebida nos modernismos teológicos respectivos que introduzem a ciência na forma de crítica histórica como técnica de observação; 3) a rejeição das ideologias políticas que se apresentam como transformadores da ordem tradicional: natural e religiosa; 4) desde que ambas as tendências são manifestações formatadas no cerne do pensamento cristão.

É importante a determinação dos sinais de partida do fundamentalismo protestante observando ser decisivo para a análise destacarmos que a terminologia adquiriu através das épocas uma evidente polissemia, gerando o que Martin Dreher chama de "uso inflacionário" do conceito. ${ }^{23}$

Uma definição plausível parte do entendimento que o fundamentalismo é produto de um amplo contexto histórico no qual agem transformações culturais, demográficas e tecnológicas, e, por tais razões, se instaura como objeto de debate

\footnotetext{
21 VELASQUES FILHO, P.; MENDONÇA, A. G. Introdução ao Protestantismo no Brasil. 2. ed. São Paulo: Loyola, 2002, p. 112-114.

${ }^{22}$ Cf. principalmente: GALINDO, F. O fenômeno das seitas fundamentalistas. A conquista evangélica da América Latina. Petrópolis: Vozes, 1995. KIENZLER, K. El fundamentalismo religioso: cristianismo, judaísmo, islamismo. Madrid: Alianza Editorial, 2000. KUNG, Hans. Contra o fundamentalismo romano-católico hodierno. In: Revista Concilium, cit., p. 149-159. LATHULIÈRE, P. Le fondamentalisme catholique. Signification et ecclésiologie. Paris: Editions du Cerf, 1995. MOLINER PRADA, A. Fèlix Sardà i Salvany y el integrismo en la Restauración. Barcelona: Universitat Autònoma de Barcelona, Servei de Publicacions, 2000.

23 DREHER, M. N. Para entender o fundamentalismo. São Leopoldo: Unisinos, 2002, p. 79.
} 
interdisciplinar. Este último aspecto impulsionou a necessidade de abordá-lo não só pela vertente teológica, mas também pelas possibilidades psicológicas, psiquiátricas e sociológicas. Tais foram os desafios enfrentados pelos estudiosos reunidos pela revista Concilium duas décadas atrás.

Se o fundamentalismo, pela amplitude que pode tomar o conceito e sua respectiva aplicação em contextos culturais díspares é um fenômeno que atinge igrejas e religiões, também atinge os mais diversos setores da sociedade. Marty (1992) tomou como referência o princípio de oposicionismo como caráter teológico fundamental dos modernos fundamentalismos. Por oposicionismo, entendeu a posição de antagonismo que ilumina todos os aspectos da teologia. Neste sentido, o fundamentalismo nas diversas religiões nada tem em comum, inevitável e necessariamente, quanto à substância teológica. Cada um existe, prossegue Marty, "para que seus líderes possam tomar distância e fazer oposição às afirmações de outras crenças teológicas”. ${ }^{24}$

Aliado a essa aspecto, Marty atribuiu ao fundamentalismo vários tipos de rejeição: à hermenêutica, na medida em que os fundamentalistas partilham a convicção de que um texto, como a bíblia, é uma revelação divina e completamente acessível admitindo, porém, um só sentido; rejeição ao plural e ao relativo dado o caráter corrosivo que reside nessas formas, bem como à resistência de os fundamentalistas ouvirem outras e provavelmente legítimas opiniões; rejeição à evolução e ao desenvolvimento.

Sociologicamente, o fundamentalismo tem alcance tanto religioso quanto político. Seu aspecto mobilizador não permite a acomodação a elementos da modernidade, e se alicerça na pretensão de moldar esses elementos à sua mentalidade. Dessa forma, o fundamentalismo é visto como uma manifestação moderna de oposição seletiva ao moderno, por contestar "o processo de separação funcional de uma sociedade", ${ }^{25}$ mas também, colocar à prova as estruturas religiosas hegemônicas que norteiam as sociedades para superá-las e instalar seus princípios gerais de imutabilidade em relação às verdades bíblicas que devem ser realizadas no mundano. Neste sentido, o espírito de missão revelado pelos movimentos evangélicos norte-americanos impactou a história eclesiástica de outros países. Na América Latina em geral, e no Brasil em

${ }^{24}$ MARTY, M. E. O que é fundamentalismo? Perspectivas teológicas. Revista Concilium, cit., p. 13-26.

25 COLEMAN, J. A. Fundamentalismo Global. Perspectivas Sociológicas. Revista Concilium, cit., p. 53-64. 
particular, umas das justificativas para a presença cada vez maior de missões religiosas e missionários a partir da segunda metade do século XIX era a necessidade de implantar um amplo projeto de cristianização e salvar as nações do catolicismo, considerado uma crença pagã. Transplantar o sonho religioso norte-americano para o solo dos países latino-americanos revestia a ideia de realizar o "destino" para o qual estava reservada a potência do norte.

Neste sentido, é evidente que os movimentos fundamentalistas constituem um desses novos movimentos ou desdobramentos das potencialidades e antinomias da agenda política da modernidade. O argumento desenvolvido por Eisenstadt (1997), de que as estreitas relações do fundamentalismo com a modernidade manifestam-se em muitas de suas características organizacionais, como a rígida disciplina partidária, a utilização das modernas tecnologias de comunicação e das modernas técnicas de propaganda parece encontrar respaldo na própria forma de divulgação dos Fundamentos. ${ }^{26}$ Em 1909, os magnatas do petróleo, Milton e Lyman Stewart financiaram a publicação dos textos fundamentais. Com o intuito de combater as incursões do liberalismo, os volumes foram enviados gratuitamente a ministros do evangelho, missionários, supervisores das escolas dominicais, calculando-se em três milhões de exemplares a distribuição no mundo de fala inglesa.

É bem verdade que existem controvérsias entre alguns autores sobre o contexto exato no qual as designações "fundamentalismo" ou "fundamentalista" passaram a fazer parte do vocabulário corrente norte-americano. Os Fundamentos pouco auxiliam na elucidação, limitando-se a referir que na "Conferência Mundial sobre os Fundamentos Cristãos", realizada em Filadélfia, em meados de 1919, um dos organizadores, William Bell Riley teria sentenciado do alto de sua pretensão: “O futuro olhará de volta para a Conferência Mundial como um evento mais histórico do que a fixação, em Wutenberg, das noventa e cinco teses de Martinho Lutero". 27 Malgrado haver certa concordância entre Velasques Filho e Reily quanto às possíveis origens do fundamentalismo, ambos se afastam quanto à autoria da designação, com o primeiro acompanhando a especulação indicada pelos Fundamentos, e o outro, atribuindo a autoria ao jornalista

26 EISENSTADT, S. N. Fundamentalismo e Modernidade. Heterodoxias, Utopismo e jacobinismo na constituição dos movimentos fundamentalistas. Trad. Ana Luisa Faria. Oeiras: Celta Editora, 1997.

27 Cf. Os Fundamentos, cit., p. 13. 
Curtis Lee Laws, no ano de 1920. ${ }^{28}$ Por último, Whiterup e Armstrong concordam em todos os sentidos com relação à origem do termo, enquanto Kepel apresenta a versão mais dissonante de todas. ${ }^{29}$ O que podemos afirmar é que as terminologias fundamentalismo e fundamentalista se desenvolvem depois da primeira guerra mundial e na esteira das conferências bíblicas organizadas, para ganhar ímpeto na década de 1920 e sofrer intermitências no período que vai do fim do Scopes Trial até inícios da década de 1970. ${ }^{30}$ Pode-se, dessa forma, propor arbitrariamente três fases para o fundamentalismo norte-americano ao longo do século XX: 1) 1910-1925: eventos que estão entre a publicação dos Fundamentos, e a erosão do criacionismo motivada pelo Scopes Trial: fase de aclimatação, ascensão e derrota política: 2) 1926-1970: fase de oscilações e de certo declínio, tendo em vista as tendências liberalizantes na política, na sociedade e nas igrejas; o impacto das teorias secularizantes e dos movimentos de contracultura e de direitos civis: fase determinada pela tentativa de restauração; 3) 1970 em diante: fase de revitalização dos movimentos fundamentalistas; reforço da militância e crescimento sem precedentes dos números de igreja e adeptos; ascensão de líderes

28 Segundo Velasques Filho "A designação fundamentalista foi atribuída a essa tendência do conservadorismo protestante na ocasião da Conferência Mundial dos Cristãos Fundamentalistas em 1919. Alguns autores [entre eles Reily] atribuem a origem do nome a Curtis Lee Lewis. Ocorre, entretanto, que a conferência mundial antecedeu o escrito de Laws. Como organização ela já existia desde a Conferência Bíblica do Niágara, celebrada em 1878”. Cf. VELASQUES FILHO, P.; MENDONÇA, A. G., cit., p. 123. Duncan A. Reily observa que o movimento fundamentalista remonta "à Conferência Bíblica do Niágara" e o "rótulo fundamentalista foi cunhado por Curtis Lee Laws, batista, redator do Watchman-Examiner, em 1920". Cf. REILY, D. A. História Documental do Protestantismo no Brasil. 3. ed. São Paulo: ASTE, 2003, p. 421.

${ }^{29}$ Whiterup assinala: "Em 1920, um jornalista batista do norte de nome Curtis Lee Laws cunhou o termo fundamentalista com referencia àqueles que aderiram às 'doutrinas religiosas fundamentais', e um grupo batista teria assumido o rótulo como uma autodesignação". Cf. WHITERUP, R. D. Fundamentalismo bíblico. Trad. Alda da Anunciação Machado São Paulo: Editora Ave-Maria, 2004, p. 127. Armstrong é quase idêntica: "Num encontro da Northern Baptist Convention, em 1920, Curtis Lee Laws definiu 'fundamentalista' como alguém que está disposto a recuperar territórios perdidos para o Anticristo e a lutar pelos fundamentos da fé". Cf. ARMSTRONG, K. Em nome de Deus: o fundamentalismo no judaísmo, no cristianismo e no islamismo. Trad. Hildegard Feist, São Paulo: Companhia das Letras: 2001, p. 202. Kepel destoa completamente: 'La aparición pública del término 'fundamentalismo' suele datarse en la década de los veinte. (...) Pero fue sobre todo el caso Scopes el que introdujo la palavra 'fundamentalismo' en el vocabulario americano corriente". Cf. KEPEL, G. La revancha de Dios. Cristianos, judíos y musulmanes a la reconquista del mundo. Madrid: Alianza Editorial, 2005, p. 153.

$30 \mathrm{O}$ atribulado Scopes Trial, ou Processo dos Macacos, refere-se à disputa entre criacionistas e evolucionistas no âmbito da educação pública do Estado do Tennessee (EUA) em 1925, e que envolveu o professor de uma escola secundária da cidade de Dayton, John T. Scopes, processado por membros da comunidade protestante pelo emprego de métodos evolucionistas a partir do manual Civic Biology de George Hunter. O caso ficou famoso ao ponto de merecer uma peça de teatro e três versões cinematográficas. Sobre o Processo, cf. DARROW, C.; LARSON, E. J. The essencial writings of Clarence Darrow. New York: Random House, 2007. MORAN, J. P. The Scopes Trial. A Brief History with Documents. New York: Palgrave, 2002. 
vocacionados para a pregação eletrônica e com estreitas relações com o poder político; uso estendido de todas as tecnologias de informação possíveis.

Esses avanços e recuos do fundamentalismo no protestantismo norte-americano não impediram que os Fundamentos se constituíssem em apologia bíblica diante do temor pela perda de mecanismos de salvação. Os textos se expressam em pequenas comunidades temáticas que evidenciam vários recusas: colocar em questão a criação e a autoria do Pentateuco, a autenticidade dos profetas e dos quatro evangelhos, a revelação, o nascimento virginal, a deidade e a ressurreição, a expiação substitutiva, a submissão da teologia à filosofia, desconfiança quanto aos testemunhos e avanços dos métodos arqueológicos que descontroem possivelmente a verdade das escrituras, o testemunho da unidade orgânica da bíblia, a segunda vinda de Cristo que inaugura o milênio.

$\mathrm{Na}$ opinião dos fundamentalistas, a melhor qualificação para perceber a verdade bíblica é a compreensão espiritual e não a filologia, exercício que se revela insuficiente de apreender uma passagem qualquer das escrituras. Desse modo, a teologia moderna seria fundada numa espécie de fraude exegética, que por sua vez constrói uma fraude literária cujo pressuposto é atribuir aos textos bíblicos uma não-historicidade. Em outras palavras, para os primeiros fundamentalistas a teologia moderna se apoia na tese de que alguns relatos bíblicos dos mais impressionantes e cruciais foram escritos posteriormente e não por quem atua como instrumento da inspiração divina.

A bíblia, texto revelado por essa inspiração, pelo "sopro do Espírito", ao contrário dos livros escritos por homens, cuja proposta é a de difundir informação e instrução, é sempre a mais atualizada, a melhor e a única autoridade em todos os assuntos. Ela está muito à frente da ciência humana com sua vivacidade perene, "sua resistência indestrutível ao obsoleto". Um ponto de honra dos fundamentalistas refere-se à doutrina da criação. Segundo Canon Dyson Hague, nos seus primeiros capítulos, o livro de Gênesis é o mais importante da bíblia porque responde satisfatoriamente a perguntas de interesse perpétuo: o ser de Deus, a origem do universo, a criação do homem, a origem da alma, o fato da revelação, a origem do pecado, a promessa de 
salvação, a divisão primitiva da raça humana, o chamado de Israel, a parte preliminar do programa redentor de Deus. ${ }^{31}$

Ainda quanto à doutrina da criação, ela se constitui na base de segurança para que tudo na natureza e na providência esteja na dependência de Deus e à sua disposição. Não há como imaginar que houvesse algo no universo que "não fosse criado por Deus, que existisse independentemente Dele", pois, do contrário, "como poderíamos estar certos de que esse elemento não poderia frustrar, vencer ou destruir o cumprimento do propósito de Deus?". ${ }^{32}$ Imune ao tempo concreto da história, a bíblia é guardiã da eternidade e responde pelas sucessivas economias do tempo divino, fato sobrenatural inesgotável e recomposto indefinidamente. Essa obediência da história ao desígnio do perene se realiza pelo sistema interpretativo eleito pelos fundamentalistas como o essencial de sua hermenêutica: o dispensacionalismo. Desenvolvido no século XIX por John Nelson Darby (1800-1882), o dispensacionalismo encontra o alvo último da história no estabelecimento do reino milenar sobre a terra. No entanto, antes dessa concretização, o mundo humano conectado à vontade e ao juízo de Deus, atravessa outras escalas de tempo, ou economias, ou dispensações. Cada dispensação é distinguível no desenrolar do propósito de Deus: "Uma dispensação é o método distintivo de Deus governar a humanidade ou um grupo de homens durante certo período da história humana, marcado por um evento, teste, fracasso e juízo crucial". ${ }^{33}$

Para cada dispensação está o homem sujeito a uma prova de dignidade que compreende administrar os frutos doados por Deus. Para cada ato falho ou para cada fracasso nessa administração, Deus profere um juízo que dispara uma nova economia que se abre para novas provas e juízos. A dispensação mais expressiva dos Fundamentos é o milênio, tanto para pré-milenistas quanto para pós-milenistas. O texto de Rosenbury Erdman assegura que a vinda de Cristo será pessoal. Por pessoal, ele crê a vinda como visível, corporal, local, ou seja, tudo que pode ser contrastado com aquilo que é espiritual, providencial, figurativo. $\mathrm{O}$ mistério da vinda está na iminência, que indica tanto a incerteza quanto à possibilidade de proximidade. Portanto, toda a sugestão sobre a determinação do tempo da vinda deve ser cautelosa: “... vigiai e orai;

31 HAGUE, C. D. O valor doutrinal dos primeiros capítulos de Gênesis. In: Os Fundamentos, p. 105106.

${ }^{32}$ ORR, J. As primeiras narrativas de Gênesis. In: Os Fundamentos, p. 52.

${ }^{33}$ RYRIE, C. C. Dispensacionalismo. Ajuda ou Heresia? Trad. Elizabeth Charles Stowell Gomes. Mogi das Cruzes: ABECAR, 2004. 
porque não sabeis quando será o tempo (Mc 13.33). Estas declarações... sugerem cautela àqueles que afirmam que a nossa era está agora chegando ao fim; pode ser, mas não há nenhuma certeza quanto a isso". 34

\section{Encontros e desencontros - integristas e fundamentalistas}

A convergência epocal com vistas a corrigir e contrapor os modernismos respectivos; o antipluralismo como pressuposto a aniquilar a crítica não reconhecendo a historicidade dos fenômenos, e, por consequência, o impulso condenatório destinado aos grupos dissonantes que propõem abordagens distintas sobre os dispositivos da fé e o controle totalizante desses mesmo dispositivos, são características semelhantes visíveis entre o integrismo e o fundamentalismo. ${ }^{35}$ As razões sociais gerais, como acentua Eisenstadt, são também fortes componentes que implicam na cristalização de um grande número de novos estilos de vida heterogêneos que redundam em: fator de corrupção, enfraquecimento das tendências existentes, evolução como ameaça, potencial corrosão das premissas básicas da religião em virtude da tônica posta em critérios aparentemente extra-religiosos. ${ }^{36}$ No entanto, os elementos simétricos observados em um e outro não dizem tudo, muito menos alcançam a multiplicidade de distinções, mesmo que consideremos a diversificação moderna como argumento central para aproximar integristas e fundamentalistas.

Uma diferença importante, embora matizada, entre o integrismo e o fundamentalismo, é quanto ao ambiente. Tanto cultural como territorialmente ambos germinam em universos diferenciados. O integrismo, em sua ambientação latina e forte ambição teocrática e absolutista, tem na Europa católica o centro do mundo e sua alavanca civilizatória, estabelecendo Roma como capital desse mundo. O fundamentalismo, fincado na tradição anglófona, recorre à bíblia sem qualquer constrangimento para afirmar a supremacia racial jafética da nação americana no campo industrial, comercial e político, sem, contudo, desmerecer o papel dos latinos,

\footnotetext{
34 ERDMAN, C. R. A vinda de Cristo. In: Os Fundamentos, p. 689-698.

35 Desse modo, Ivo Pedro Oro sublinha a seguinte questão: "Uma vez que a conjuntura sócio-histórica é similar, não obstante a diferença de contextos confessionais, pode-se sugerir que sua emergência e desenvolvimento se dão em fatores sociológicos comuns, os movimentos que os geram são os que conflitam com os movimentos modernistas. Isto leva a gerar, principalmente na mente e na boca dos seus adversários, comparações e identificações de posição teológica e opção ideológico-política". Cf. ORO, I. P. O outro é o demônio: uma análise sociológica do fundamentalismo. São Paulo: Paulus, 1996, p. 39.

36 EISENSTADT, cit., p. 76.
} 
germânicos e outros. Reconhece que um dos seus fins é se consagrar a uma missão mundial que tem em vista a conversão de todos os povos. Este foi um argumento dos missionários quando iniciaram os processos de entrada das denominações protestantes na América latina:

Os fatos da história têm cumprido o que foi predito em Gêneses há quatro mil anos, As nações camitas, incluindo os caldeus, os babilônicos e os egípcios, foram degradadas, profanas e sensuais. A semita foi a dos religiosos, de onde veio o Messias. A jafética foi a das raças que mais cresceram e tornaram-se dominantes, incluindo todas as monarquias mundiais, tanto dos tempos antigos quanto modernos, a grega, a romana, a gótica, a céltica, a teutônica, a britânica e a americana, assim como investigações e descobertas recentes, as raças da Índia, China e Japão. Assim, Cam perdeu todo o império séculos atrás; Sem e sua raça adquiriram esse império ética e espiritualmente pelo Profeta, Sacerdote e Rei, o Messias; ao passo que Jafé, abarcando o mundo e aumentando a supremacia imperial tem estado no domínio industrial, comercial e político. ${ }^{37}$

Do ponto de vista de mediação em termos de ligação com Deus e interpretação exegética observa-se uma profunda e crucial distinção. O desprezo e o pessimismo quanto à dimensão e capacidade de ação histórica do homem confere aos fundamentalistas a necessidade de aplicação da bíblia a todas as situações práticas da vida. Ela é apropriada para confirmas as certezas, e não é objeto de indagações. A tradição remonta diretamente e sem intermediários de um ser superior. ${ }^{38} \mathrm{O}$ homem, dentro desse enfoque, desaparece como agente e se transmuda num instrumento, num depósito da vontade divina, pela qual, florescem os elementos formais do fundamentalismo. Podemos apreendê-los de modo mais claro na relação desequilibrada construída por Philip Mauro entre teologia revelada e filosofia. ${ }^{39}$

Para Mauro, a filosofia e a revelação são conciliáveis se, e somente se, Philosophia ancilla theologiae. A própria existência da filosofia como uma ocupação para a mente humana depende da rígida exclusão de toda explicação do universo que não seja alcançada por um processo especulativo. A filosofia como arte, ciência, invenção do homem, porque especulativa e curiosa do sentido das coisas, é reveladora

\footnotetext{
37 HAGUE, cit., p. 118.

38 "La característica que mejor define la actitud fundamentalista es su negativa a recurrir a la mediación hermenêutica en la lectura de los textos fundantes de las religiones. Se cree que éstos han sido revelados diretamente - o mejor, dictados - por Dios, tienen un solo sentido, el literal, y una única interpretación, la que emana de su lectura directa". Cf. TAMAYO, J. J. Fundamentalismo y dialogo entre religiones. Madrid: Editorial Trotta, 2004, p. 87. [Grifos no original].

39 MAURO, P. A filosofia moderna. In: Os Fundamentos, p. 575-589.
} 
da fraqueza humana e de sua propensão a seduzir-se pelo conhecimento. Mauro, neste aspecto, sustenta que a filosofia não é "segundo Cristo", pela simples e suficiente razão de que o testemunho de Cristo põe fim a tudo que ela aceita, a todas as especulações filosóficas concernentes às relações da humanidade com Deus e com o universo. Segundo Mauro, as revelações não são apenas diametralmente opostas às especulações filosóficas, mas retiram todo e qualquer fundamento destas. A doutrina de Cristo "não somente instrui os homens quanto ao caminho para o reino de Deus, mas também autoriza aqueles que o aceitam à posse imediata e o desfrutar de muitos e valiosos direitos e privilégios que não podem ser adquiridos de outro modo”. 40

Ora, se a posse de direitos e privilégios é imediata, não há razão plausível para engendrar um esforço teórico e reflexivo que o campo da filosofia exige. Parece que Mauro contribui para instalar a monossemia característica da relação entre homem e Deus no fundamentalismo, e se recusa a perceber que, se os homens não precisam da reflexividade filosófica, tampouco prescindem da teologia, uma vez que a verdade e o sentido já estão determinados, digeridos e aptos para uso. Assim, se ocorre um rebaixamento da filosofia, a recíproca quanto à revelação também se realiza e "o livro" pode permanecer fechado, a não ser quando pretendamos nos certificar da verdade localizando o versículo apropriado para resolver uma dada situação.

Ao contrário, no integrismo católico o apelo à verdade revelada e sua compreensão acontece a pretexto de zelar pela tradição. Até que ponto podemos ousar afirmar que essa tradição não se constrói por uma deliberação hierárquica autoritária e não sofre, a partir dessa deliberação, um processo de degeneração? A autoridade do magistério eclesiástico, desde que infalível, mesmo que prescrita por "homens mortais", resulta na produção de um dogmatismo exacerbado, materializado pela ânsia do decretismo francamente disposto a eliminar as tensões, condená-las, ou controlá-las, como foi observado na querela modernista. O tipo de mediação imposta pelo integrismo sugere a desigualdade radical entre pastores e rebanho, à conta, justamente, do lugar no qual se aloja a tradição. O discurso sobre a apropriação da tradição eclesiástica, no caso do integrismo, é, sublinha Moingt (1992), enganoso.

Moingt sugere que no integrismo há uma inversão no funcionamento da tradição. Há inversão, quando a tradição, que consiste em dizer de outra maneira o dizer

${ }^{40}$ Idem, p. 579-580. 
original, se apresenta como a origem mesma. ${ }^{41}$ A autoridade da tradição está contida pelo autoritarismo religioso. É ela quem define o enunciado da tradição sem permitir que haja a recriação marginal interpretativa do dado de origem e conforme as contingências do tempo histórico, porque tal atitude recai na heresia. A tradição, processo instituinte e constituinte, sempre em reconstrução criativa, degenera em tradicionalismo, norma instituída e constituída.

Enquanto no fundamentalismo, é a bíblia, porque a bíblia é Deus, quem julga sobre o bem e o mal, sobre a corrupção e a pureza; no integrismo católico é o tradicionalismo da alta ecclesia, socorrido pela antiguidade, quem previne sobre os perigos do livre exame e pune as resistências individuais. O "fundamento" católico, legalizado no ato da chancela magisterial infalível passa a ser uma classificação seriada de discursos que convergem para o representante de Deus: o ritual, a instituição, a deliberação conciliar, a encíclica, a bula, a constituição dogmática, o papa. O integrismo idolatra o centralismo e o burocratismo. Almeja integrar a religião na política pela integração do Estado na Igreja e se ressente profundamente com as políticas de laicização. O integrismo visa canonizar o mundo da política quando procura associar-se ao Estado para compartilhar, em termos de produção, controle e usufruto de um projeto de poder. Certas configurações de Estado seduzem os integristas: normalmente, estados autoritários e fortes, encobertos por suspeitável constitucionalidade, com chefes paternais travestidos de carisma pela propaganda, que perseguem e anulam ideologias políticas opostas tendem a exercer um fascínio nos integristas, como, em tempos distintos ou simultâneos, pode-se observar no varguismo, no franquismo e em ditaduras militares sul americanas. Nesses casos, não raras vezes, os integristas derivam de um integrismo doutrinal para um integrismo ético, social, caridoso, associado ao damaísmo filantrópico e desejam vê-lo expresso em normas constitucionais. O integrismo, historicamente, intensifica o antiprotestantismo católico na medida em que a corrosão modernista radica, dentre outras fontes, da teologia liberal protestante. Mas não satisfaz tão somente com seu antimodernismo. Quase tudo aquilo que se percebe como ameaça, que se opõe como ideia recebe o epíteto de moderno, de "progressismo", e com maior ou menor grau, é remetido à interpretação e censura da bíblia do integrismo: a Pascendi.

\footnotetext{
41 MOINGT, J. Religiones, Tradiciones y Fundamentalismos. Selecciones de Teologia, vol. 31, , n. 122,
} p. 178, Abril-Junio 1992. 
Em contrapartida, o fundamentalismo protestante clássico, antes de anticatólico é antirromano e tripudia a concepção de que o catolicismo absorve sua vontade da tradição. À questão “O romanismo é cristianismo?”, Medhurst desenvolve uma série de reflexões que complementam, a crítica ao tradicionalismo. O romanismo é uma invenção hostil ao cristianismo real, uma vez que não é, de fato, cristianismo. Por quê? O romanismo não professa ser fundado apenas nas Escrituras; ele reivindica um direito de partir do que está contido nelas - um direito para acrescentar às Escrituras ao fazer novos decretos. Ele diz que os concílios e o Papa foram autorizados pelo Espírito Santo a fazer decretos pelos quais, na realidade, as doutrinas entregues por Cristo são completamente anuladas. ${ }^{42}$

Ademais, Medhurst denuncia a ânsia persecutória do centro romano em direção aos adversários; aos que ousam compreender por si as Escrituras; aos que desafiam a obediência:

\begin{abstract}
Alguns dizem que Roma deixou de perseguir. Mas este não é o fato; seja quanto aos seus atos, seja quanto [a] regras de ação, ela afirma que é inalterada e imutável; que é infalível e não pode mudar, exceto se a necessidade, ou planos para o futuro, exigirem isso. Os fatos, que provam que a perseguição ainda é aprovada por ela, estão frequentemente ocorrendo. Quando Roma tem pouco poder, seu espirito de perseguição é mantido por um tempo; mas ainda está ali. Quando está livre da restrição, não conhece nenhum outro meio de tratar com a diferença de opinião senão pela tortura, pela estaca, pelo parafuso da tortura, pela bota de ferro, pelo punhal do assassino ou massacre em massa. ${ }^{43}$
\end{abstract}

Não podemos responder com eficácia em que medida tais perseguições, tendo em perspectiva as variações históricas, podem ser atualizadas. É certo, porém, que os fundamentalistas apregoavam sobre a existência e vitalidade de uma única e verdadeira igreja para acentuar seu antirromanismo. Diziam, inclusive, que a Igreja católica romana era a antagonista da nação, e operava como um sistema "político-eclesiástico e é inimiga essencial e fatal da liberdade civil e religiosa, a antagonista grisalha tanto da igreja [verdadeira] como do estado". ${ }^{44}$ Em síntese, o papado tirava a coroa da cabeça de Cristo e a colocava na cabeça do papa. ${ }^{45}$

\title{
Considerações finais
}

\footnotetext{
${ }^{42}$ MEDHURST, T. W. O romanismo é cristianismo? In: Os Fundamentos, p. 531-541.

43 Idem, p. 535-536. [Grifos no original].

44 FOSTER, J. M. Roma, a antagonista da nação. In: Os Fundamentos, p. 543-551.

45 MEDHURST, cit., p. 539.
} 
Os dogmatismos religiosos discutidos não transigem nas suas demandas mais profundas e são portadores de uma vitalidade de elementos que ressignificam no presente histórico o debate sempre aberto, e controverso, entre religião e sociedade. As questões que foram colocadas por integristas e fundamentalistas, nos seus correspondentes pontos de partida motivam muitas implicações atuais sobre os dividendos simbólicos que regulam o maior ou menor grau de publicidade das crenças, a competição entre elas, e as políticas que presidem a relação dessas tendências mais intransigentes entre si e entre outras esferas.

Há que se valorizar a questão da dicotomia antiintelectualismo versus intelectualismo que realça uma distinção importante na relação entre o fundamentalismo e o integrismo, fundada, ela mesma, quando emergiram os conflitos com os respectivos movimentos modernistas. $\mathrm{O}$ fundamentalismo seria um dos produtos do antiintelectualismo norte-americano, tendo em vista a rejeição à alta crítica, e, na origem, a afronta revivalista à racionalidade erudita do puritanismo que foi o núcleo de onde frutificou o protestantismo na América inglesa.

Já o integrismo católico com seu apego irremediável não à tradição, mas aos mecanismos de monopolização dessa tradição degenerou em tradicionalismo e tendeu a hipertrofiar a autoridade. A exacerbação doutrinária levada ao paroxismo e sem concessões às transformações culturais submeteu os dados sociais a sua moral, marcando um discurso de intelectualismo autoritário que lançou olhares de reprovação ou reservas para as manifestações populares da religião, e para as manifestações reformistas saídas da teologia. Em síntese, condenou os diversos níveis de consciência pelos quais era possível alcançar a dimensão do sagrado.

Não obstante, embora de complexas e conflitivas consequências culturais, religiosas e políticas, como o demonstram a trajetória e o fenômeno da multiplicidade denominacional evangélica, é possível que o dilema fundamentalista tenha uma capacidade menos exígua de resolução no confronto com seus rivais, protestantes ou não. Essa capacidade nasce, justamente, do conflito que produz a diluição apontada, na medida em que a liberdade de trânsito denominacional própria ao protestantismo é invocada quando as disputas de carismas, ideologia, economias e doutrina se manifestam. Ainda cabe assinalar que no final dos anos 1980, com o eclipse definitivo dos movimentos de contracultura, tal como foram concebidos duas ou três décadas 
antes, surgiram outras perspectivas. Elas acontecem graças aos mecanismos tecnológicos, informacionais e políticos que estão sob administração dos movimentos fundamentalistas, e também de integristas - e por que não pensar na FSSPX (Fraternidade Sacerdotal São Pio X) como uma dessas instâncias de produção de sentidos que se opõe ao moderno estando contido nele?

O entrelaçamento contraditório de um individualismo utilitário, egocêntrico e a religião, o surgimento multiplicado de novos movimentos religiosos e correntes exotéricas alternativas, assim como o revival flutuante das religiões históricas, isto é, um exercício confuso e pontuado nas fronteiras de secularização e dessecularização, são fatores que estão sempre a exigir um (re) posicionamento de integristas e fundamentalistas, dos seus herdeiros e dos seus simpatizantes.

\section{Referências}

ABBagnano, N. Dicionário de Filosofia. Trad. Alfredo Bosi. 2. ed. São Paulo: Martins Fontes, 1998.

ARMSTRONG, K. Em nome de Deus: o fundamentalismo no judaísmo, no cristianismo e no islamismo. Trad. Hildegard Feist. São Paulo: Companhia das Letras: 2001.

DARROW, C.; LARSON, E. J. The essencial writings of Clarence Darrow. New York: Random House, 2007.

DREHER, M. N. Para entender o fundamentalismo. São Leopoldo: Unisinos, 2002.

EISENSTADT, S. N. Fundamentalismo e Modernidade. Heterodoxias, Utopismo e jacobinismo na constituição dos movimentos fundamentalistas. Trad. Ana Luisa Faria. Oeiras: Celta Editora, 1997.

GALINDO, F. O fenômeno das seitas fundamentalistas. A conquista evangélica da América Latina. Petrópolis: Vozes, 1995.

GOMÁ, I. Tradición y Crítica en exégesis: orientaciones de la apologética bíblica moderna. Barcelona: Gustavo Gili Editor, 1910.

HARTLICH, C. Estará superado o método histórico-crítico? Revista Concilium/158 Ecumenismo, p. 5-11, 1980/8.

HERVIEU-LÈGER, D. O peregrino e o convertido: a religião em movimento. Trad. João Batista Kreuch. Petrópolis: Vozes, 2008. 
KEPEL, G. La revancha de Dios. Cristianos, judíos y musulmanes a la reconquista del mundo. Madrid: Alianza Editorial, 2005.

KIENZLER, K. El fundamentalismo religioso: cristianismo, judaísmo, islamismo. Madrid: Alianza Editorial, 2000.

LATHULIÈRE, P. Le fondamentalisme catholique. Signification et ecclésiologie. Paris: Editions du Cerf, 1995.

LEFEBVRE, M. Do Liberalismo à Apostasia. A Tragédia Conciliar. Trad. Ildefonso Albano Filho. Rio de Janeiro: Permanência, 1991.

LOISY, A. L'Evangile et L'Eglise. Paris: Chez L'Ateur, 1908.

Prelude to the Modernist Crisis: The Firmin Articles of Alfred Loisy American Academy of Religions in Translation. Oxford: Oxford University Press, 2010.

MADIRAN, J. L'intégrisme: histoire d'une histoire. Paris: Nouvelles Editions Latines, 1964.

MATTEI, R. de. Modernismo e antimodernismo nell'epoca di Pio X. In: BUSI, Michele, et al. Don Orione negli anni del modernismo. Milano: Editoriale Jaca Book Spa, 2002, p. 29-86.

MOINGT, J. Religiones, Tradiciones y Fundamentalismos. Selecciones de Teologia, vol. 31, , n. 122, p. 176-182, Abril-Junio 1992.

MOLINER PRADA, A. Fèlix Sardà i Salvany y el integrismo en la Restauración. Barcelona: Universitat Autònoma de Barcelona, Servei de Publicacions, 2000.

MORAN, J. P. The Scopes Trial. A Brief History with Documents. New York: Palgrave, 2002.

MOURÃO, J. A. Crítica textual e modernismo - Em torno do decreto Lamentabili e da encíclica Pascendi. Revista de Recensões de Comunicação e Cultura. Lisboa, n. 6/7, p. 365-371, 1988.

ORO, I. P. O outro é o demônio: uma análise sociológica do fundamentalismo. São Paulo: Paulus, 1996.

PIERUCCI, Antonio Flavio. Fundamentalismo e integrismo: os nomes e a coisa. Revista USP, São Paulo, n. 13, p. 144-156, mar/mai 1992.

PIO X, papa. Carta Encíclica Vehementer Nos - 11 de fevereiro de 1906: Sobre as Relações entre a Igreja e o Estado. Petrópolis: Vozes, 1952.

Carta Encíclica Pascendi Dominici Gregis - 08 de setembro de 1907. Petrópolis: Vozes, 1948. 
RYRIE, C. C. Dispensacionalismo. Ajuda ou Heresia? Trad. Elizabeth Charles Stowell Gomes. Mogi das Cruzes: ABECAR, 2004.

REILY, D. A. História Documental do Protestantismo no Brasil. 3. ed. São Paulo: ASTE, 2003.

Revista Concilium, Petrópolis, 241 - Dossiê Ecumenismo, 1992-3.

SCHLEGEL, J. L. A lei de Deus contra a liberdade dos homens: integrismos e fundamentalismos. Trad. de Eduardo Brandão. São Paulo: Editora WMF Martins Fontes, 2009.

TAMAYO, J. J. Fundamentalismo y dialogo entre religiones. Madrid: Editorial Trotta, 2004.

TORREY, R. A. Os Fundamentos: a famosa coletânea de textos das verdades bíblicas fundamentais. Editado por R. A. Torrey; atualizado por Charles L. Feinberg e outros; introduções biográficas de Warren W. Wiersbe. Trad. Cláudio J. A. Rodrigues. São Paulo: Hagnos, 2005.

VELASQUES FILHO, P.; MENDONÇA, A. G. Introdução ao Protestantismo no Brasil. 2. ed. São Paulo: Loyola, 2002.

WHITERUP, R. D. Fundamentalismo bíblico. Trad. Alda da Anunciação Machado São Paulo: Editora Ave-Maria, 2004.

ZAGHENI, G. A idade contemporânea. Curso de História da Igreja IV. Trad. José Maria de Almeida. São Paulo: Paulus, 1998.

Recebido:28/06/2012

Received: 06/28/2012

Aprovado: 28/11/2012

Approved: 11/28/2012 